\title{
Analysis Technical and Allocative Efficiency of the Usage of CPO Production Factors In PT. Sandabi Indah Lestari, Padang Jaya Sub-Distrct, North Bengkulu Regency
}

\author{
Dwi Tia Sukmawati1), Irnad 2), Bambang Sumantri2) \\ 1)Study Program of Agribusiness Magister Faculty of Agriculture, University of Bengkulu \\ 2) Department of Agricultural Socio-Economics, Faculty of Agriculture, University of \\ Bengkulu \\ Email: 2) bsumantri719@yahoo.com
}

\begin{abstract}
The present study was aimed to analyze the levels of technical and allocative efficiency of the usage of CPO production factors in PT. Sandabi Indah Lestari. The data being used was primary and secondary data. The data analysis to measure technical efficiency was Cobb-Douglas frontier production function and production elasticity value, while allocative efficiency was analyzed using NPMxi to Hxi ratio. The research result showed that fresh fruit bunch (TBS), indirect labor (TKTDL), and fiber (FB) had significant positive effect on CPO production in PT. Sandabi Indah Lestari, while direct labor (TKL), solar fuel (SR), $\mathrm{CaCO}_{3}$, and Nalco N 8507 (N8507) didn't have significant positive or negative effect on CPO production in PT. Sandabi Indah Lestari. Fresh fruit bunch (TBS), indirect labor (TKTDL), and fiber (FB) were technically efficient $(0<\mathrm{EP}<1)$. Conversely, allocatively fresh fruit bunch (TBS), indirect labor (TKTDL), and fiber (FB) were'nt efficient (NPMxi/Hxi>1).
\end{abstract}

Keywords : production factors, technical efficiency, allocative efficiency, frontier production function, production elasticity, NPMxi to Hxi ratio

Reference to this paper should be made as follows :

Sukmawati, D. T., Irnad, B. Sumantri. 2019. Analysis Technical and Allocative Efficiency of The Usage of CPO Production Factors in PT. Sandabi Indah Lestari, Padang Jaya Sub-District, North Bengkulu Regency. Agritropica: Journal of Agricultural Science. 3 (1): 1-12. Doi:

https:// doi.org/10.31186/Jagritropica.3.1.1-12

\section{INTRODUCTION}

Oil palm is one of the main commodities which affect Indonesia's economic growth, so it attracts people and is cultivated by people and companies. Temporary number shows that the size of oil palm plantation in Indonesia in 2017 was estimated to increase by 9.80 percent in 2016 to 12.30 million hectares (Central Bureau of Statistics, 2017).

Along with the increasing size of oil palm plantations, national oil palm production in the form of crude palm oil (CPO) also continues to increase. It's because of the increase global demand for $\mathrm{CPO}$, drawing people to do business in oil palm plantation as smallholding plantation (PR), major public $(\mathrm{PBN})$, and major private plantation (PBS).
The average growth of private plantations in the last 10 years is 7.62 percent, smallholding plantations 7.37 percent, and public plantations has the smallest average growth of 1.75 percent. Similarly, the growth rate of crude palm oil (CPO) production of private plantations in Indonesia is the highest (11.46 percent), while smallholding plantations is 7.36 percent and public plantations only 3.09 percent. It showed that of the three plantation types, private plantations dominate oil palm plantations in Indonesia in terms of cultivation area growth and crude palm oil (CPO) production (Ministry of Agriculture, 2018).

One of the provinces in Indonesia which has many oil palm plantations is Bengkulu. Like other provinces, oil palm plantations in Bengkulu are usually run by private companies. One of the companies is 
PT. Sandabi Indah Lestari. PT. Sandabi Indah Lestari is a palm oil company in North Bengkulu Regency and owns a mill to process oil palm into CPO. PT. Sandabi Indah Lestari has 3 plantations in Bengkulu Provinces in Lubuk Banyau, Seluma and Ketahun.

CPO production in the palm oil mill of PT. Sandabi Indah Lestari requires various production factors, e.g. fresh fruit bunch, labor, water, fuel such as solar fuel and fiber and chemicals. The usage of production factors requires the company to allocate production factors efficiently to get optimal outcome without high cost. In other words, not wasting production factors.

PT. Sandabi Indah Lestari has palm oil mill with installed capacity of 45 tons per hour. Based on the installed capacity, it's found that the production needs the company must meet is 1,080 tons per day. This is the maximum production needs of PT. Sandabi Indah Lestari. Actually, 1,080 ton per day hasn't been met by the company. Based on interview with the company, only 60 percent of the production needs of PT. Sandabi Indah Lestari are met. It's because fresh fruit bunch supply from company plantations and smallholding plantations is insufficient, so that production needs aren't fully met. Company plantations usually contribute 20 percent of the fruits, while the remaining 40 percent is met by smallholding plantations. It shows that the production of PT. Sandabi Indah Lestari isn't maximal because the material supply can't keep up with the installed capacity of the company.

Beside production material issue, the management in labor hour supervision in PT. Sandabi Indah Lestari should be noted. Based on field observation, it's found that the working hours of processing labor is too high, indicating that the current labor hour can't maximize $\mathrm{CPO}$ production. Excessive working hour is caused by poor control or supervision to the overtime of processing employees in PT. Sandabi Indah Lestari. Water usage, especially for domestic needs, is often wasted. Employees or local community often use water without turning off the tap, so the water keeps flowing and is wasted. The water which should be used for processing is also used to wash vehicles. Moreover, solar fuel usage is quite high because the fresh fruit bunches were insufficient. The less fresh fruit bunches is processed, the higher the solar fuel usage.

As a big company, PT. Sandabi Indah Lestari must maintain good performance and use every production input optimally. Therefore, the efficiency of production factor usage should be measured to analyze whether the production factors used by PT. Sandabi Indah Lestari are efficient or not. The method to analyze the efficiency of production is technical efficiency and allocative efficiency analysis.

\section{RESEARCH METHODS}

\section{Method of Collecting Data}

The study was performed on April 2019 in PT. Sandabi Indah Lestari Kecamatan Padang Jaya, North Bengkulu Regency. The data being used was primary and secondary data. Primary data was obtained from direct observation at the field and interview with respondents. The respondents in the present study were mill manager, assistants, mill employees and other parties related to the study. Primary data included installed capacity and effective capacity of the company, production factors used in producing $\mathrm{CPO}$ and their usage in production process, CPO production process in PT. Sandabi Indah Lestari in the last 4 years (20152018), company history, organizational structure, and tasks/authority of every position in the company.

Secondary data was the data obtained directly from PT. Sandabi Indah Lestari through mill manager from 2015 to 2018 or 48 observation months, covering total production factors used in 2015 to 2018, such as fresh fruit bunch, direct labor, indirect labor, water, solar fuel, fiber, $\mathrm{CaCO}_{3}$, and Nalco $\mathrm{N}$ 8507, CPO production in 2015 to 2018, CPO price in 2015 to 2018, expenses in 2015 to 2018, company budget, and other data related with the study.

\section{Data Analysis Method}

\section{Technical Efficiency \\ The data was processed} mathematically, then tabulated and explained 
descriptively. According to Yoko et al (2014) and Septian et al., (2015) the data analysis to measure technical efficiency is Cobb-Douglas frontier production function. The frontier production function for $\mathrm{CPO}$ production was assumed to have Cobb-Douglas form which could be written in the following equation.

$$
\begin{gathered}
Y=\alpha+ \\
\beta_{1} \mathrm{TBS}+\beta_{2} \mathrm{AR}+\beta_{3} \mathrm{TKL}+\beta_{4} \mathrm{TKTDL}+\beta_{5} \mathrm{SR}+\beta_{6} \mathrm{FB}+\beta \\
{ }_{7 \mathrm{CaCO} 3}+\beta_{8} \mathrm{~N} 8507+\left(\mathrm{V}_{\mathrm{i}}-\mathrm{U}_{\mathrm{i}}\right)
\end{gathered}
$$

The equation was transformed into natural logarithm to be able to estimate the parameters. The equation in the natural logarithm form is as follows:

Ln $Y=\alpha+\beta_{1}$ Ln TBS $+\beta_{2}$ Ln AR+ $\beta_{3}$ Ln TKL + $\beta_{4}$ Ln TKTDL $+\beta_{5}$ Ln SR $+\beta_{6}$ Ln FB $+\beta_{7}$ Ln

$$
\mathrm{CaCO} 3+\beta_{8} \operatorname{Ln} \mathrm{N} 8507+\mathrm{V}_{\mathrm{i}}-\mathrm{U}_{\mathrm{i}}
$$

Note :

$$
\begin{aligned}
\mathrm{Y} & =\text { total } \mathrm{CPO} \text { production }(\mathrm{kg} / \mathrm{mth}) \\
\mathrm{TBS} & =\text { fresh fruit bunch }(\mathrm{kg} / \mathrm{mth}) \\
\mathrm{AR} & =\text { water }\left(\mathrm{m}^{3} / \mathrm{mth}\right) \\
\mathrm{TKL} & =\text { direct labor }(\text { hour } / \mathrm{mth}) \\
\mathrm{TKTDL} & \quad=\text { indirect labor }(\text { hour } / \mathrm{mth}) \\
\mathrm{SR} & =\text { solar fuel }(\text { liter } / \mathrm{mth}) \\
\mathrm{FB} & =\text { fiber }(\mathrm{kg} / \mathrm{mth}) \\
\mathrm{CaCO}= & \mathrm{CaCO} 3(\mathrm{~kg} / \mathrm{mth}) \\
\mathrm{N} 8507= & \text { Nalco } \mathrm{N} 8507(\mathrm{~kg} / \mathrm{mth}) \\
\mathrm{a} & =\text { intercept } \\
\mathrm{Vi} \quad= & \text { error in production } \\
\mathrm{Ui} & =\text { error } \\
\beta_{1}-\beta_{8}= & \quad \text { estimator variable parameter } \\
& \text { (regression coefficient of production } \\
& \text { factor })
\end{aligned}
$$

Wahyuningsih et al. (2018) states that technical efficiency analysis could be determined through production factor elasticity (Ep) in regression equation using Cobb-Douglas production function model which is transform into Ln (natural logarithm). $\mathrm{Ep}=\mathrm{bi}$ or (regression equation) with the provisions:

a. If $0<\mathrm{Ep}<1$ the usage of production factor is technically efficient

b. If $\mathrm{Ep}>1$ the usage of production factor is still technically inefficient, so the usage of production factor can be

\section{increased}

c. If $\mathrm{Ep}<0$ the usage of production factor is already inefficient, so the usage of production factor should be reduced.

\section{Allocative Efficiency}

Wibishanna and Mustadjab (2015) state that allocative efficiency can be analyzed by comparing marginal product value (NPMxi) with production input price (Hxi). Mathematically it can be written as follows:

$$
\mathrm{k}=\frac{\mathrm{NPMxi}}{\mathrm{Hxi}}=1
$$

With the provisions :

$\mathrm{k}=\frac{\mathrm{NPMxi}}{\mathrm{Hxi}}>1$, means the usage of input $\mathrm{X}$ is inefficient and should be increased.

$\mathrm{k}=\frac{\mathrm{NPMxi}}{\mathrm{Hxi}}=1$, means the usage of input $\mathrm{X}$ is efficient.

$\mathrm{k}=\frac{\mathrm{NPMxi}}{\mathrm{Hxi}}<1$, means the usage of input $\mathrm{X}$ is inefficient and should be reduced.

Note :

NPMxi $=$ marginal product value of the $i^{\text {th }}$ production factor

$\mathrm{Hxi}=$ price of the $\mathrm{i}^{\text {th }}$ production factor

$\mathrm{k}=$ efficiency index value

\section{RESULTS AND DISCUSSION}

\section{Results of Classical Assumption Test}

Test on the lack of autocorrelation, multicollinearity and heteroscedacity should be performed to determine whether the equations are good to make estimation. The results of classical assumption tests are described below.

\section{Multicollinearity Test}

Multicollinearity could be determined from Variance Inflation Factor (VIF) which didn't exceed 10 . The result of preliminary test showed that the equation model contained multicollinearity as the VIF of water is very high. Widarjono (2013) describes multicollinearity as linear relation between independent variables in a regression. Multicollinearity cause estimator to have big variant and covariant, so it's difficult to get 
accurate estimation. Moreover, multicollinearity also will produce high coefficient of determination but few significant independent variables. One way to remove multicollinearity is removing independent variable which has strong linear relation or the biggest VIF.

Tabel 1. Variance Inflation Factor Values of Production Factors Affecting CPO Production Process in PT. Sandabi Indah Lestari After Water Was Removed

\begin{tabular}{lc}
\hline \multicolumn{1}{c}{ Variable } & VIF (Variance Inflation Factor) \\
\hline Fresh Fruit Bunch (Ln TBS) & 3.893885 \\
Direct Labor (Ln TKL) & 3.836469 \\
Indirect Labor (Ln TKTDL) & 4.051575 \\
Solar Fuel (Ln SR) & 1.168387 \\
Fiber (Ln FB) & 3.402704 \\
$\mathrm{CaCO}_{3}(\mathrm{Ln} \mathrm{CaCO})$ & 2.035172 \\
Nalco N 8507 (Ln N8507) & 1.261156 \\
\hline
\end{tabular}

Source : Processed Secondary Data (2019)

Based on the VIF values in the table above, it's concluded that the equation model didn't have multicollinearity because VIF values don't exceed 10 .

\section{Autocorrelation Test}

The result of preliminary test showed that the equation model contained autocorrelation. According to Widarjono (2013), autocorrelation can be tested by Breusch-Godfrey method known as Lagrange Multiplier (LM) test in which is the chi-square probability value is bigger than the selected $a$, then the equation doesn't contain autocorrelation. Conversely, if the probability value is smaller than the selected $a$, then there is autocorrelation. Beside this method, autocorrelation also can be found using Durbin-Watson value. Equation which contains autocorrelation should be fixed so that the equation can be used to perform estimation. One of the methods is first difference method.

The table above showed the result of the autocorrelation test after performing first equation model, there was no multicollinearity issue anymore. Below is the result of multicollinearity test after water was removed from the equation model.

difference method improvement and fixing multicollinearity issue. The chi-square probability value from Breusch-Godfrey method of LM test is 0.6427 and bigger than a $=5$ percent, so it's concluded that the equation model doesn't have autocorrelation.

The Durbin-Watson value is 1.847540 , while DW table ( $\alpha=1$ percent) has $d L$ value of 1.039 and $\mathrm{dU}$ value of 1.748 . If $\mathrm{d}$ is bigger than $\mathrm{dU}$ and smaller than 4 less than $\mathrm{dU}$, there is no positive or negative autocorrelation. It showed that $\mathrm{d}$ is bigger than $\mathrm{dU}(1.748)$ and smaller than 4 less than dU (2.252), so it's concluded that there is no autocorrelation.

\section{Heteroscedacity Test}

Heteroscedacity can be detected using Breusch Pagan Godfrey method in which $p$ value shown by chi-square probability in Obs*R-Squared should be bigger than the selected a value. The result of heteroscedacity test after fixing autocorrelation and multicollinearity is shown in the table below.

Table 2. Result of autocorrelation test after using first difference method

\begin{tabular}{llll}
\hline F-Statistic & 0.354673 & Prob. F (2.37) & 0.7038 \\
\hline Obs*R-Squared & 0.884111 & Prob. Chi-Square (2) & 0.6427 \\
\hline
\end{tabular}

Source : Processed Secondary Data (2019) 
Table 3. Result of heteroscedacity test after fixing autocorrelation and multicollinearity

\begin{tabular}{llll}
\hline F-Statistic & 0.709580 & Prob. F (7,39) & 0.6640 \\
\hline Obs*R-Squared & 5.309699 & Prob. Chi-Square (7) & 0.6222 \\
\hline Scaled explained SS & 4.012437 & Prob. Chi-Square (7) & 0.7783 \\
\hline
\end{tabular}

Source : Processed Secondary Data (2019)

The chi-square probability value is 0.6222 and bigger than $a=5$ percent, so it's concluded that the equation model is free from heteroscedacity.

Based on the results of the three tests, it's ensured that the equation model is good and can be used to to estimate production factors affecting $\mathrm{CPO}$ production in PT. Sandabi Indah Lestari.

\section{Result of Regression Analysis of Factors Affecting CPO Production in PT. Sandabi Indah Lestari}

The result of regression analysis of factors affecting CPO production in PT. Sandabi Indah Lestari is shown in the table below.

Table 4. Result of Regression Analysis of Factors Affecting CPO Production in PT. Sandabi Indah Lestari

\begin{tabular}{lccccc}
\hline \multicolumn{1}{c}{ Variable } & $\begin{array}{c}\text { Regression } \\
\text { Coefficient }\end{array}$ & $\begin{array}{c}\text { Std. } \\
\text { Error }\end{array}$ & t-count & Prob-t & Des. \\
\hline Interception & -0.0000294 & 0.004499 & $-0,006532$ & 0,9948 & \\
Fresh Fruit Bunch (Ln TBS) & 0.739759 & 0.063587 & 11,63375 & 0,0000 & $* *$ \\
Direct Labor (Ln TKL) & 0.015338 & 0.065729 & 0,233356 & 0,8167 & \\
Indirect Labor (Ln TKTDL) & 0.203506 & 0.075896 & 2,681367 & 0,0107 & $*$ \\
Solar Fuel (Ln SR) & -0.010133 & 0.011322 & $-0,0895010$ & 0,3763 & $*$ \\
Fiber (Ln FB) & 0.096992 & 0.039189 & 2,474969 & 0,0178 & $*$ \\
CaCO $_{3}$ (Ln CaCO 3$)$ & 0.002263 & 0.025509 & 0,008707 & 0,9298 & \\
Nalco N 8507 & -0.008944 & 0.007176 & $-1,246365$ & 0,2201 & \\
$($ Ln N8507) & F-count $=140.4064$ & \multicolumn{2}{c}{ Dw $=1.847540$} & \\
\multicolumn{1}{c}{$\mathrm{R}^{2}=0.961834$} & & &
\end{tabular}

Source : Processed Secondary Data (2019)

Note :

** $\quad=$ very significant at $\alpha=5$ percent

* $\quad=$ significant at $\alpha=5$ percent

$\mathrm{F}_{\text {table }}(0.05 ; 6 ; 40)=2.336$

$\mathrm{t}_{\text {table }}(0.05 ; 40) \quad=1.684$

Based on the analysis result in table 4 , the following equation was produced:

Ln $Y=-0.0000294+0.739759$ Ln TBS + 0.015338 Ln TKL + 0.203506 Ln TKTDL - 0.010133 Ln $\mathrm{SR}+0.096992 \mathrm{Ln} \mathrm{FB}+0.002263$ Ln CaCO3 - 0.008944 Ln N8507

\section{Result of Coefficient of Determination $\left(\mathbf{R}^{2}\right)$ Calculation}

The analysis result showed that $\mathrm{R}^{2}$ (coefficient of determination) is 0.961834, meaning 96.1834 percent of CPO production was simultaneously affected by independent variables in the study, while the remaining 3.8166 percent was affected by other factors not in the model.

\section{Result of F Test}

The result of $\mathrm{F}$ test showed that $\mathrm{F}$ count is 140.4064 and bigger than $\mathrm{F}$ table of 2.336, meaning all variables, i.e. fresh fruit bunch, direct labor, indirect labor, solar fuel, fiber, $\mathrm{CaCO}_{3}$, and Nalco N 8507 simultaneously significantly affected $\mathrm{CPO}$ production in PT. Sandabi Indah Lestari. 


\section{Result of $t$ Test (Partial Test)}

The effect of each independent variable individually (partially) on $\mathrm{CPO}$ production in PT. Sandabi Indah Lestari is below:

\section{Fresh Fruit Bunch (TBS)}

The regression coefficient of fresh fruit bunch is 0.739759 , meaning 1 percent addition of fresh fruit bunch would increase CPO production by 0.739759 percent, assuming other production factors were constant (cateris paribus). Based on the result of regression analysis, $t$ count is 11.63375 with $t$ probability value of fresh fruit bunch of 0.000 and very significant at $\alpha=5$ percent. $t$ count is bigger than $t$ table, which is 1.684. It meant fresh fruit bunch usage had significant positive effect on CPO production in PT. Sandabi Indah Lestari and was the most dominant production factor.

The average usage of fresh fruit bunches of PT. Sandabi Indah Lestari was $16,366,829.42$ kilograms per month, while the installed capacity of the company was 45 tons per hour, total maximum production needs was 27,000,000 kilograms per month. According to Pardamean (2014), the common effective processing capacity of palm oil mill is 90 percent of installed capacity with 22 hours processing hours, so that the total production needs the company should meet was $22,275,000$ kilograms per month. It showed that the usage of fresh fruit bunches hadn't met effective processing capacity and installed capacity. The usage of fresh fruit bunches in CPO production is very important because they're the main material in producing CPO.

This was in line with the study by Azzuhdan et al (2014), in which average fresh fruit bunch used by Selucing Agro Mill-Palm Oil Mill (PKS-SAGM) is only 25,927,429 kilograms per month, while on certain months, the total fresh fruit bunches used can reach $35,401,897$ kilograms. It shows that the total fresh fruit bunches being used hasn't met the optimal capacity of PKS-SAGM, so the fresh fruit bunches can be increased.

\section{Direct Labor (TKL)}

The result of regression analysis showed that $t$ count is 0.233356 with $t$ probability value of 0.8167 and is insignificant at $\alpha=5$ percent. $t$ count is smaller than $t$ table of 1.684, so it's concluded that direct labor doesn't have significant positive or negative effect on CPO production in PT. Sandabi Indah Lestari.

Direct labor is labor which directly handles production process and can be directly connected to finished goods (Syafitri and Putra, 2018). The average usage of direct labor of PT. Sandabi Indah Lestari was 20,608.46 hours per month. Direct labor consisted of 2 shifts, i.e. process shift 1 and process shift 2. Process labor started from loading ramp, sterilizer, thresher, tippler, pressing, clarification, kernel, water treatment, boiler, incinerator, to engine room. Based on regression analysis, direct labor didn't affect CPO production in PT. Sandabi Indah Lestari. It was because $\mathrm{CPO}$ production was performed by machines and human labor only acted as operators of the production machines.

The research result was consistent with the study by Damanik and Nugroho (2017) which states that labor only has small effect on $\mathrm{CPO}$ processing because the whole production process is performed by machines and human only acts as operators. Moreover, Septian et al., (2015) finds that labor has negative and insignificant effect on total CPO production in PT. Perkebunan Nusantara VI of South Solok.

\section{Indirect Labor (TKTDL)}

The regression coefficient of indirect labor from the analysis result is 0.203506 , meaning every 1 percent addition of indirect labor would increase CPO production by 0.203506 percent, assuming that other production factors were constant (cateris paribus). The $t$ count produced by the analysis is 2.681367 with $t$ probability value of 0.0107 and is significant at $a=5$ percent. $t$ count is bigger than $t$ table of 1.684 . It meant indirect variable had significant positive effect on $\mathrm{CPO}$ production in PT. Sandabi Indah Lestari.

Indirect labor is labor who works to smooth production process and isn't involved in production process directly. Indirect labor 
consisted of sorting, maintenance, and laboratory. The average usage of indirect labor of PT. Sandabi Indah Lestari was 12,375.49 hours per month. Based on regression analysis, indirect labor had positive effect on CPO production in PT. Sandabi Indah Lestari, meaning indirect labor could be increased to increase CPO production. It was because indirect labor contained sorting labor related with the main material in producing $\mathrm{CPO}$ which is fresh fruit bunches.

The research result was supported by Hermawan et al (2015) who state that fresh fruit bunch to be processed must meet predetermined requirements from factory to get good production outcome. Therefore, every incoming fresh fruit bunch must be sorted by grading operator. The sorting includes fruit ripeness, fruit damage, fruit physical shape, loose fruit, etc.. Good quality fresh fruit bunch will produce good quality CPO.

Beside sorting labor, indirect labor also covered maintenance labor who maintained production machines and laboratory labor who controlled or supervised the usage of chemicals required in production and ensured $\mathrm{CPO}$ product was consistent with the preset target and standard, especially in terms of quality.

In the study by Azzuhdan et al. (2014), it's explained that labor has positive effect on CPO production in PKS-SAGM. Similarly, Purba's study (2013) finds that labor has positive effect on CPO production in PT. Perkebunan Nusantara IV of North Sumatera.

\section{Solar Fuel (SR)}

The $t$ count is -0.895010 with $t$ probability value of 0.3763 and is insignificant at $\alpha=5$ percent. $t$ count is smaller than $t$ table of 1.684 , so it's concluded that solar fuel doesn't have significant positive or negative effect on CPO production in PT. Sandabi Indah Lestari.

Solar fuel is fuel resulting from distillation of clear yellow brown oil (Syafriuddin and Hanesya, 2012). The average usage of solar fuel of PT. Sandabi Indah Lestari is 8,738.52 liter per month. Based on regression analysis, solar fuel didn't have significant effect on CPO production in PT.
Sandabi Indah Lestari. It was because solar fuel was only used to power the factory generator set at the start of CPO production before being replaced by fiber.

Solar fuel was only used to power generator set to warm up production machines before processing. After all machines were hot and the mill was ready for processing, it would be replaced by fiber as boiler fuel to move turbines. Solar fuel usage would increase if the mill only processed a little fresh fruit bunches. The more fruits were processed, the less the solar fuel was used, and the more fiber was produced.

This was in line with the study of Utami (2013) which states that fuel doesn't have significant effect on CPO production in PT. Gersido Minang Plantation, while Azzuhdan et al (2014) find that fuel has negative effect on CPO production in PKSSAGM.

One of the examples of rather large solar fuel usage was on July 2017 (31 st period) when solar fuel usage was $14,715.00$ liter. It was because in that month boiler number 2 was repaired and mill capacity lowered, so electricity must be supported by generator set which uses solar fuel.

\section{Fiber (FB)}

The regression coefficient of fiber is 0.096992, meaning every additional 1 percent of fiber would increase CPO production by 0.096992 percent, assuming other production factors were constant (cateris paribus). $\mathrm{t}$ count is 2.474969 with $t$ probability value of 0.0178 and is significant at $a=5$ percent. $t$ count is bigger than $t$ table of 1.684 , so it's concluded that fiber has significant positive effect on $\mathrm{CPO}$ production in PT. Sandabi Indah Lestari.

Fiber is the solid waste of fresh fruit bunch processing produced by depericarper, which is used as boiler fuel to produce steam and to generate electricity (Afifah et al, 2016). The average usage of fiber of PT. Sandabi Indah Lestari was 2,451,956.65 kilograms per month. Based on regression analysis, fiber had positive effect on $\mathrm{CPO}$ production in PT. Sandabi Indah Lestari, meaning fiber usage could be increased. It was because fiber was the main fuel for processing fresh fruit bunches into CPO. 
Haryanti et al (2014) explain that fiber from oil palm is an alternative replacement for solar fuel and coal to generate electricity. Fiber is used as boiler fuel to boil by steaming oil palm before processing. Harris et al (2013) also state that shell and fiber are used as fuel in PLTU $6 \mathrm{MW}$ to heat up water in boiler to produce steam temperature and steam pressure to spin steam turbine. When using fiber, PLTU 6 MW has average output of 2.3 $\mathrm{MW} /$ hour and in $1 \mathrm{MW}$ output requires 1.83 tons of fiber.

\section{$\mathrm{CaCO}_{3}$}

The $t$ count is 0.0887087 with $t$ probability value of 0.9298 and is insignificant at $\alpha=5$ percent. $t$ count is smaller than $t$ table of 1.684, so it's concluded that $\mathrm{CaCO}_{3}$ doesn't have significant positive or negative effect on $\mathrm{CPO}$ production in PT. Sandabi Indah Lestari. $\mathrm{CaCO}_{3}$ is chemical used to increase the specific gravity of water so that core and shell separate more easily. The average usage of $\mathrm{CaCO}_{3}$ was 17,495.21 kilograms per month.

The research result was in line with Utami (2013) who states that chemical doesn't have significant effect on CPO production in PT. Gersido Minang Plantation with $t$ count smaller than $\mathrm{t}$ table. Meanwhile, Azzuhdan et al (2014) find that $\mathrm{CaCO}_{3}$ has positive effect on $\mathrm{CPO}$ production by 0.19 percent. It shows that
$\mathrm{CaCO}_{3}$ addition will increase $\mathrm{CPO}$ production in PKS-SAGM.

\section{Nalco N 8507 (N8507)}

The $t$ count is -1.246365 with $t$ probability value of 0.2201 and is insignificant at $\mathrm{a}=5$ percent. $\mathrm{t}$ count is smaller than $\mathrm{t}$ table of 1.684, so it's concluded that Nalco N 8507 doesn't have significant positive or negative effect on CPO production in PT. Sandabi Indah Lestari. The usage of Nalco N 8507 affected the quality of water used for the operation of boiler. Nalco N 8507 is used to increase $\mathrm{pH}$ of boiler feedwater. The average usage of Nalco N 8507 was 73.19 kilograms per month.

Utami's (2013) study also finds that chemical doesn't affect CPO production in PT. Gersido Minang Plantation. Furthermore, Azzuhdan et al (2014) states that alum doesn't have significant effect on CPO production in PKS-SAGM and has regression coefficient of 0.09 , meaning increased usage of alum will reduce CPO production in PKS-SAGM.

Analysis of Technical Efficiency of the Usage of CPO Production Factors in PT. Sandabi Indah Lestari

The result of technical efficiency analysis of CPO production factors in PT. Sandabi Indah Lestari can be seen in the table below.

Table 5. Result of Technical Efficiency Analysis of CPO Production Factors in PT. Sandabi Indah Lestari

\begin{tabular}{lcc}
\hline \multicolumn{1}{c}{ Production Factor } & Production Elasticity & Conclusion \\
\hline Fresh Fruit Bunch & 0.739759 & Efficient \\
Indirect Labor & 0.203506 & Efficient \\
Fiber & 0.096992 & Efficient \\
Total (Business Scale) & $\mathbf{1 . 0 4 0 2 5 7}$ & Increasing Return to Scale \\
\hline
\end{tabular}

Source : Processed Secondary Data (2019)

Technical Efficiency of Fresh Fruit Bunch (TBS)

The production elasticity of fresh fruit bunch in CPO production is 0.739759 and is 0 $<$ Ep $<1$, meaning that the usage of fresh fruit bunch was in production area II or rational production area, meaning technically fresh fruit bunches were used efficiently.

This was in line with the study by Hermawan et al (2015) which states that production elasticity of material (TBS) is positive, which is 0.985 . The elasticity value shows that the material is in area II, which is rational area because the production elasticity is between zero and one. Moreover, Azman (2014) also explains that the most dominant elasticity value of fresh fruit bunch is 0.76 , meaning adding 1 percent of fresh fruit bunches will increase $\mathrm{CPO}$ production by 0.76 percent. 
Technical Efficiency of Indirect Labor (TKTDL)

The production elasticity of indirect labor in CPO production is 0.203506 and is $0<$ $\mathrm{Ep}<1$, meaning that the usage of indirect labor was in production area II or rational production area, meaning indirect labor was technically efficient.

According to Purba (2013), the production elasticity of labor in CPO production in PT. Perkebunan Nusantara IV is 0.3092, showing that the usage of labor is in area II, which is rational area, because the production elasticity is between zero and one. Labor was the most responsive production factor because it had the biggest elasticity compared with other production factors. The study by Saragih et al (2015) also explains that the technical efficiency of labor in PKS PT. Sinar Sawit Lestari is 0.80, meaning labor usage is technically efficient. The closer to 1 the efficiency is, the higher the technical efficiency in CPO production.

\section{Technical Efficiency of Fiber (FB)}

The production elasticity of fiber in $\mathrm{CPO}$ production is 0.096992 and is $0<\mathrm{Ep}<1$, meaning that the usage of fiber was in production area II or rational production area, meaning fiber was technically efficient.

Fiber is a fuel to replace solar fuel which is used for boiler to produce steam which moves turbine. PT. Sandabi Indah Lestari uses fiber as the main fuel to process fresh fruit bunches into CPO. This was to utilize solid waste produced by processing and reduce fuel cost. A study by Syafriuddin and Hanesya (2012) explains that shell and fiber are effective alternative fuel in electric steam power pant because it's cheap and has small environmental impact compared with coal and solar fuel.

\section{Business Scale Analysis}

According to Hermawan et al (2015), business scale describes a proportional increase of all production inputs against the output. In Cobb-Douglass function, business scale is found by totaling all regression coefficients of the independent variables in model. The result of estimate regression coefficient of CPO production factors in PT. Sandabi Indah Lestari is 1.040257 and bigger than 1, meaning CPO production in PT. Sandabi Indah Lestari was increasing return to scale, meaning adding production factors would produce increased production with bigger proportion. Adding 1 percent of production input would increase production result by 1.040257 percent.

This condition was in line with the study by Azman (2014) that the business scale of palm oil mills in Malaysia is 1.05 and bigger than 1, meaning the palm oil mills are in a state of increasing return to scale, in which if it increases input usage by 1 percent, it will increase production result by 1.05 percent.

\section{Analysis of Allocative Efficiency of the Usage of CPO Production Factors in PT. Sandabi Indah Lestari}

The result of analysis of allocative efficiency of the usage of CPO production factors in PT. Sandabi Indah Lestari is shown in the table below.

Table 6. Result of Analysis of Allocative Efficiency of the Usage of CPO Production Factors in PT. Sandabi Indah Lestari

\begin{tabular}{ccccccc}
\hline $\begin{array}{c}\text { Production } \\
\text { Factor }\end{array}$ & Xi (unit) & PMxi & NPMxi & Hxi & k & Conclusion \\
\hline \multirow{2}{*}{ TBS } & $\begin{array}{c}16,366,829.42 \\
\mathrm{~kg} / \mathrm{mth}\end{array}$ & $\begin{array}{c}0.15 \\
\mathrm{~kg} / \mathrm{mth}\end{array}$ & $\begin{array}{c}\mathrm{Rp} 1,265.19 / \mathrm{kg} / \\
\mathrm{mth}\end{array}$ & $\begin{array}{c}\mathrm{Rp} 1,260.41 / \\
\mathrm{kg}\end{array}$ & 1.004 & inefficient \\
\hline TKTDL & $\begin{array}{c}12,375.49 \\
\text { hours } / \mathrm{mth}\end{array}$ & $\begin{array}{c}53.77 \\
\mathrm{~kg} / \mathrm{mth}\end{array}$ & $\begin{array}{c}\mathrm{Rp} 460,302.53 / \mathrm{ho} \\
\mathrm{ur} / \mathrm{mth}\end{array}$ & $\begin{array}{c}\mathrm{Rp} 10,287.93 \\
/ \mathrm{hour}\end{array}$ & 44.74 & inefficient \\
\hline FB & $\begin{array}{c}2,451,956.65 \\
\mathrm{~kg} / \mathrm{mth}\end{array}$ & $\begin{array}{c}0.13 \\
\mathrm{~kg} / \mathrm{mth}\end{array}$ & $\begin{array}{c}\mathrm{Rp} 1,107.27 / \mathrm{kg} / \\
\mathrm{mth}\end{array}$ & $\begin{array}{c}\mathrm{Rp} 165.00 / \\
\mathrm{kg}\end{array}$ & 6.71 & inefficient \\
\hline
\end{tabular}

Source : Processed Secondary Data (2019)

Note $: \mathrm{Y} \quad=3,269,861.94 \mathrm{~kg} / \mathrm{mth}, \mathrm{Hy} \quad=\mathrm{Rp} 8,560.50 / \mathrm{kg}$ 


\section{Allocative Efficiency of the Usage of Fresh Fruit Bunch (TBS)}

The comparison of marginal product value to fresh fruit bunch is bigger than 1, which is 1.004 , meaning that the usage of fresh fruit bunches wasn't efficient at the applicable price, so the amount of fresh fruit bunches should be increased to make the usage of the production factor at efficient level $\mathrm{k}=1$.

The average usage of fresh fruit bunch in $\mathrm{CPO}$ production in PT. Sandabi Indah Lestari is $16,366,829.42$ kilograms per month at $\mathrm{Rp} 1,260.41$ per kilogram. The usage of fresh fruit bunch could be increased to increase $\mathrm{CPO}$ production result. Based on the company's installed capacity of 45 tons per hour, total maximum production needs was 27,000,000 kilograms per month, while Pardamean (2008) states that the common effective processing capacity of palm oil mill is 90 percent of the installed capacity with 22 processing hours. It meant the production needs which should be met by the company was 22,275,000 kilograms per month. The production needs of PT. Sandabi Indah Lestari was only 60 percent of the installed capacity because the material supply from their own plantations and smallholder plantations was inadequate.

The marginal product for fresh fruit bunch was 0.15 kilogram per month, meaning the usage of 1 kilogram of fresh fruit bunch would increase CPO production by 0.15 kilogram per month, while the marginal product value of fresh fruit bunch was $\mathrm{Rp}$ $1,265.19$ per kilogram per month. It meant that the added CPO production value from adding 1 kilogram of fresh fruit bunch was $\mathrm{Rp}$ 1,265.19 per month.

Utami (2013) explains that the usage of fresh fruit bunch in PT. Gersido Minang Plantation is 23,783 ton per month, while based on the installed capacity of the company, total maximum fresh fruit bunch is 37,440 tons per month, so it's concluded that fresh fruit bunch usage can be increased. Optimum production factors from production efficiency calculation is 36,075 ton per month and it can be said to be rational because the optimum production factor almost reaches the installed capacity of the company.

\section{Allocative Efficiency of the Usage of Indirect Labor (TKTDL)}

The comparison of marginal product value to indirect labor was 44.74 and bigger than 1 , meaning the usage of indirect labor was inefficient at the applicable price and should be added to make it efficient or $\mathrm{k}=1$.

The average usage of indirect labor was 12,375.49 hours per month at $\operatorname{Rp~10,287.93~}$ per hour. Based on the efficiency analysis, total usage of labor could be increased and followed by increasing proportionally processed fresh fruit bunches to increase $\mathrm{CPO}$ production result.

The marginal product from the result of efficiency analysis was 53.77 kilograms per month, meaning 1 hour usage of indirect labor would increase $\mathrm{CPO}$ production by 53.77 kilograms per month, while the marginal product value of indirect labor was $R p$ $460,302.53$ per hour per month, meaning that the added CPO production value from adding 1 hour from indirect labor hour was $\mathrm{Rp}$ $460,302.53$ per month.

\section{Allocative Efficiency of the Usage of Fiber (FB)}

The ratio of marginal product value to fiber was 6.71 and bigger than 1, meaning fiber usage was inefficient at the applicable price and should be added to make it allocatively efficient or $\mathrm{k}=1$.

The average usage of fiber in PT. Sandabi Indah Lestari was 2,451,956.65 kilograms per month at $\mathrm{Rp} 165.00$ per kilogram. Based on efficiency analysis, it was found that total usage of fiber could be increased to increase $\mathrm{CPO}$ production.

The marginal product from the analysis was 0.13 kilogram per month, meaning using 1 kilogram of fiber would increase CPO production by 0.13 kilogram per month. The marginal product value of fiber

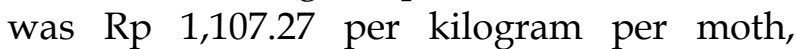
meaning the added production value from adding 1 kilogram of fiber as $\mathrm{Rp} 1,107.27$ per month.

\section{Usage of Optimal Production Factors}

The average usage of optimal production factors of $\mathrm{CPO}$ production in $\mathrm{PT}$. 
Sandabi Indah Lestari can be seen in the table below.

Table 7. Usage of Optimal Production Factors in CPO Production in PT. Sandabi Indah Lestari

\begin{tabular}{lcc}
\hline \multicolumn{1}{c}{ Production Factor } & Actual Xi & Optimal Xi \\
\hline Fresh Fruit Bunch (TBS) & $16,366,829.42 \mathrm{~kg} / \mathrm{mth}$ & $16,428,786.57 \mathrm{~kg} / \mathrm{mth}$ \\
Indirect Labor (TKTDL) & $12,375.49 \mathrm{hour} / \mathrm{mth}$ & $553,704.32 \mathrm{hour} / \mathrm{mth}$ \\
Fiber (FB) & $2,451,956.65 \mathrm{~kg} / \mathrm{mth}$ & $16,454,341.21 \mathrm{~kg} / \mathrm{mth}$ \\
\hline
\end{tabular}

Source : Processed Secondary Data (2019)

The average usage of fresh fruit bunch in the CPO production in PT. Sandabi Indah Lestari was 16,366,829.42 kilogram per month, while the optimal usage of fresh fruit bunch was $16,428,786.57$ kilogram per month. It showed that the usage of fresh fruit bunch by the company could be increased by $61,957.16$ kilogram per month. Total optimal usage of fresh fruit bunch isn't absolute, considering mill manager should note company condition in terms of material, production machine condition, processing hour, etc.

The average usage of indirect labor was 12,375.49 hour per month, while the optimal usage of indirect labor was 553,704.32 hours per month. It meant that the company's usage of indirect labor could be increased by $541,328.83$ hour per month. Total optimal usage of indirect labor isn't a must because mill manager should note the company condition first. Indirect labor consisted of sorting, maintenance, and laboratory. Working hour could be added by adding working hour shifts to 3 shifts with shift 1 at 07.00-15.00, shift 2 at 15.00-23.00 and shift 3 at 23.00-07.00.

The average usage of fiber was 2,451,956.65 kilograms per month, while the optimal usage of fiber was 16,454,341.21 kilograms per month. It showed that the usage of fiber by the company could be increased by $14,002,384.56$ kilograms per month. Total optimal usage of fresh fruit bunch isn't absolute, considering mill manager should note company condition before implementing it. Fiber is pulp from fresh fruit processing used as boiler fuel to move turbine. If the total fresh fruit bunch was increased, the amount of fiber would increase. Moreover, production machines such as cake breaker conveyor and depericarper also should be maintained and examined to prevent damage which reduced fiber mincing result.

\section{CONCLUSIONS AND POLICY IMPLICATIONS}

\section{Conclusions}

Based on regression analysis, fresh fruit bunch (TBS), indirect labor (TKTDL), and fiber (FB) has significant positive effect on CPO production in PT. Sandabi Indah Lestari, while direct labor (TKL), solar fuel (SR), $\mathrm{CaCO}_{3}$ and Nalco N 8507 (N8507) don't have significant positive or negative effect on $\mathrm{CPO}$ production in PT. Sandabi Indah Lestari. Based on production elasticity values, fresh fruit bunch (TBS), indirect labor (TKTDL), and fiber (FB) are technically efficient. Based on the ratio of marginal product value and production factor price, fresh fruit bunch (TBS), indirect labor (TKTDL), and fiber (FB) aren't allocatively efficient, so the usage should be increased.

\section{Recommendations}

It's suggested that the usage of each input is adjusted to reach the most potential number in the $\mathrm{CPO}$ production so that the production will be efficient to reach optimal result.

\section{REFERENCES}

Azman, I. 2014. The Impact of Palm Oil Mills' Capacity on Technical Efficiency of Palm Oil Millers in Malaysia. Malaysia. Oil Palm Industry Economic Journal. 14 (1) : 34-41.

Azzuhdan, D. A., R. Dwiastuti, dan S. Suhartini. 2015. Analisis Efisiensi Ekonomi Produksi Crude Palm Oil Di PT. Windu Nabatindo Abadi, Kabupaten Kotawaringin Timur. HABITAT, 25(3), 192-205. 
Central Bureau of Statistics. 2017. Indonesian Oil Palm Statistics. Jakarta. ISSN 19789947.

Damanik, F.L. and Nugroho, T.R.D.A. 2017. Analisis Nilai Tambah Cpo (Crude Palm Oil) di Pt. Perkebunan Nusantara Iii (Persero) Medan (Studi Kasus Pabrik Kelapa Sawit Aek Torop). Jurnal Pamator: Jurnal Ilmiah Universitas Trunojoyo, 10(1), 15-19.

Haryanti, A., Norsamsi, Sholiha, P.S.F., and Putri, N.P. 2014. Studi pemanfaatan limbah padat kelapa sawit. Konversi, 3(2), 57-66.

Hermawan, B., Edison and Damayanti, Y. 2015. Analysis of Factors Affecting Production of Crude Palm Oil (CPO) in PT. Satya Kisma Business River Bengkal Mill Tebo District. Faculty of Agriculture University of Jambi. Jambi. Sosio Ekonomika 18 (2) : 1-11.

Ministry of Agriculture. 2018. Palm Oil Outlook. Data Centre and Information System of Agriculture, Jakarta. ISSN 1907-1507.

Pardamean, M. (2008). Panduan lengkap pengelolaan kebun dan pabrik kelapa sawit. AgroMedia. Jakarta. 226 Pages.

Purba, D.K. 2013. Analysis of Factors Affecting Production of Crude Palm Oil (CPO) at Adolina Unit PT. Perkebunan Nusantara IV North Sumatera. Agribusiness Faculty of Economics and Management Bogor Institute of Agriculture. Bogor (Not Published).

Saragih, S.A.W., Salmiah., and Ayu, S.F. 2015. Efficiency Analysis of Labor Use and Production Optimization in CPO Processing. Study Program of Agribusiness Faculty of Agriculture University of North Sumatera. North Sumatera (Not Published).
Septian, E., Basri, S., \& Pailis, E. A. (2015). Analisis Faktor-faktor Yang Mempengaruhi Produksi Crude Palm Oil (Сpo) PT. Perkebunan Nusantara VI (Persero) Solok Selatan (Doctoral dissertation, Riau University).

Syafitri, Y. and Putra, M.S.S. 2018. Aplikasi Akuntansi Biaya Tenaga Kerja Langsung (BTKL) pada Stasiun TVRI Bandar Lampung. Jurnal JUSINTA, 1(1), 50-55.

Syafriuddin and Hanesya, R. 2012. Perbandingan Penggunaan Energi Alternatif Bahan Bakar Serabut (Fiber) Dan Cangkang Kelapa Sawit Terhadap Bahan Bakar Batubara Dan Solar Pada Pembangkit Listrik. Prosiding Seminar Nasional Aplikasi Sains \& Teknologi (SNAST) Periode III 162-170.

Utami, S. (2013). Analisa Efisiensi Produksi Pada Pabrik Pengolahan Kelapa Sawit Di PT Gersido Minang Plantation Kecamatan Lingkung Aur Kabupaten Pasaman Barat. Tugas Akhir. Univeritas Andalas.

Wahyuningsih, A., Setiawan, B.M., and Kristanto, B.A. 2018. Analisis Efisiensi Teknis Penggunaan Faktor Produksi, Pendapatan Tunai Usahatani Jagung Hibrida Dan Jagung Lokal Di Kecamatan Kemusu, Kabupaten Boyolali. Agromedia 36 (1) : 86-96.

Wibishanna, A. and Mustadjab, M.M. 2015. Analisis efisiensi alokatif penggunaan faktor-faktor produksi pada usahatani jagung (Zea mays L.)(Studi Kasus di Desa Dengkol, Kecamatan Singosari, Kabupaten Malang). Habitat 26 (2) : 136-143.

Yoko, B., Syaukat, Y., and Fariyanti, A. 2014. Analisis efisiensi usahatani padi di Kabupaten Lampung Tengah. Jurnal Agribisnis Indonesia, 2 (2) : 127 - 140. 